\title{
愛知県西尾市一色町に和ける 養鰻生産者の関係性とその変化
}

\author{
前田竜 孝*
}

(2016年 9 月 29 日受付， 2017 年 9 月 16 日受理)

I はじめに

1 問題の所在

2 事例地域の概要

II 一色町に拈ける養鰻業の展開

1 戦後に打忊る生産基盤の整備

2 加温式ハウスの導入とその後の経済 状況の変化

III 経営状況と集出荷作業の特徵

1 養鰻経営体の経営状況

2 養殖方式と生産暦
3 集出荷作業の種類とその内容

IV 手伝い関係の基盤となる組織

1 モンテ

2 一色らなぎ研究会

$\mathrm{V}$ 生産者間関係の変化の実態

1 関係性を重視する経営体一No.9の 事例-

2 新たな関係性を形成する経営体一 No.27の事例—

VI おわりに

本研究は，養鰻業に拈ける経済的な変化を，産地に拈ける制度的・技術的な変化と，それらに応じ た生産者間の関係性の変化に注目しながら考察した。事例地域として，日本有数の生産量を誇る愛知 県西尾市一色町を設定した。一色町の養鰻業では, 第二次世界大戦後の高度経済成長期に行政が中心 となって生産基盤が整備された。各経営体も, この時期に生産力の強化を目的として, 加温式八ウス に代表される様々な生産技術を導入した。一方で, 各経営体の経営主間の関係性はこの期間に変化し た。特に，集出荷作業に拈ける手伝い関係は，加温式八ウスの導入による作業の省力化によって解消 された。このように，養鰻産地を取り巻く経済状況と個別経営体の経営状況，生産者間の関係性は相 互に作用している。ただし，関係性の変化は経営主の経験によってそれぞれ異なるため，これらの相 互作用を明らかにするためには，各経営体の個別具体的な状況を考察することが重要となる。

キーワード : 養鰻業, 集出荷作業，労働力の確保，モンテ，愛知県西尾市一色町

\footnotetext{
*関西学院大学文学研究科・院生Ｅ-mail: maedakamome@yahoo.co.jp
} 


\section{Relationships Between Eel Producers in Isshiki Town, Nishio City, Aichi Prefecture \\ MAEDA Ryuko}

Graduate student, School of Humanity, Kwansei Gakuin University

(Received on 29 September, 2016; Accepted on 16 September, 2017)

The aim of this paper was to analyze the economic dynamics of eel production in Isshiki Town, Aichi Prefecture. This area has one of the highest volumes of eel production in Japan. In the high economic growth period after World War II, eel production increased because the administrations developed production bases, and the managing bodies attempted to introduce technologies, such as warming houses, to strengthen productivity. The relationships between managers have been transformed during this period. In particular, the relationships between the laborers picking-up and shipping eels dissolved after the introduction of the warming house, which reduced the labor required. From the above, the economic circumstances in the producing area, management of the households and the relationships between the managers continue to interact. However, it is important to consider the manager's experiences and reveal these interactions because these relationships can transform over time.

Key words: eel production, pick-up and shipping, ensure labor forces, Monte: mutual assistance to work force, Isshiki Town

\section{I はじめに}

\section{1 問題の所在}

養鰻業は，明治時代に開始されて以来，生産量・ 生産額に掠いて日本の内水面養殖業の中心を担っ てきた（増井, 2013）。その養殖形態1) は, 生産過 程において多額の資本が投下されるという特徵を もつ。これは，第二次世界大戦後の高度経済成長 期に妳ける国民所得の上昇に伴い， ウナギ食が大 衆化したことと関係する。すなわち，ウナギ需要 の増加によって各産地に扣ける生産・出荷技術の 改良が促され，資本投下型の生産・出荷体制が確
立していったのである。

こうした生産・出荷体制の強化は, 個別経営体 と各地に設置された協同組合・産地問屋によって 主導された。個別経営体では, ウナギの致死率を 下げるとともに，成長率も高めるために，生産段 階に打いて機械化がすすんだ。具体的には，池に 水を供給するための揚水ポンプ，水温を上昇させ るためのボイラー装置, 池中に酸素を送り込む摚 水車などの導入である。他方で, 協同組合と産地 問屋は，出荷サイズに達した成魚（成鰻）の販売 強化を目指した。その過程で，活魚販売にとどま らず加工品販売にも注目が集まるようになり，産

1) 養鰻業では, 種苗生産から成魚育成までの完全養殖が依然として達成されておらず, 種苗には天然のものが使用 されている。な抏, 養殖ウナギの呼称は成長段階に応じて変化する。シラスは 1 尾約 $0.2 \mathrm{~g}$ で種苗として使用さ

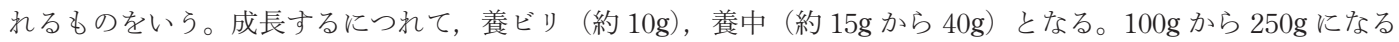
と養太と呼ばれ，これが成鰻として出荷される。養太以上のサイズは「ボク」（250g 以上）と呼ばれ，大きすぎ て身が固くなるため，販売価格は下がるという。 
地内にかば焼きや白焼きの加工場が次々と建設さ れるよらになった（塚本, 2003）。このよらに，資 本投下型の養鰻業は, 個別経営体による生産面の 強化，並びに協同組合と産地問屋による販売面の 強化が組み合わさることで確立されたのである。

以上のよらな特徵をもつ養鰻業に関する産地研 究は, 業態の成立・発展・衰退の諸過程の分析を 中心的な課題として, 漁業経済学抽よび地理学に おいて進められてきた2)。漁業経済学に抢いては, 増井（1978）が愛知県矢作川河口地域を事例とし て, 戦後の養鰻業の展開をノリ養殖業・農業と関 連づけて論じた。その後, 増井は, 静岡県大井川 河口地域でみられた, 開発主体の相違によって生 みだされた経営規模の地域差についても考察して いる（増井, 1979）。また，浜名湖沿岸地域を事例 とした研究では, 養鰻業の成立条件である水源, 種苗, 餌料が確保される過程と生産技術が導入さ れる過程について, 産地の成立から発展・衰退 までの展開が明らかにされた（増井1981, 1982a, 1982b)。一連の地域研究を通じて, 経済学的な 視点に基づく養鰻産地の形成過程が解明されたと いえる（増井, 1999）。増井が用いた業態の成立 条件に注目する研究手法は, 80年代後半以降の地 理学に打ける内水面養殖業の諸研究にも応用され ている（井村, 1987, 1994）。

その後, 養鰻業を取り巻く経済的な状況が 1970 年代のオイルショック，80年代の産地間競争の激 化とウナギ輸入量の増加，90年代以降の種苗採捕 量の減少に伴う価格の高騰3)などにより厳しさを 増すなか, 塚本 (2000) は, 熊本県玉名地区の個 別経営体の経営分析によって，外国産ウナギの輸 入量の増加に伴う価格競争が産地に及ぼした影響 を考察した。また，全県レベルでの種苗の供給体 制が整備された宮崎県を事例として，このシステ
ムが生産活動へ与える影響も明らかにした（塚本, 2001)。近年では, 産地の維持にも関心がむけら れて和り, 産地加工体制の強化や, 食のブランド 化を通じた販売力の拡大などの取り組みに関する 研究もみら机る（塚本, 2003, 2010a, 2010b, 2014）。 以上のように，養鰻産地に関する経済学・経済地 理学的研究は, 養鰻業を取り巻く経済状況を成立 条件, 生産技術の導入, 制度の整備などの諸現象 に加えて, 産地間競争や種苗不足といった広域的 な経済現象にも注目しながら考察してきた。

先行研究からも, 産地の生産力は各経営体によ る経営の改善と, 各種組織や行政による販売・流 通面の強化が組み合わさって高められてきたこと が明らかとなっている。しかし，これらによって 生じた産地の変化と各経営体の経営状況との相 互関係について考察した研究は, これまで塚本 （2000）の核かにはみられない。塚本が指摘する ように，産地の経済的な変化を考察するらえでは， 産地全体の経済的な動態を分析するとともに，産 地の発展を担ってきた各経営体や生産者にもより 一層注目していくことが重要となる。

このような問題意識のもと, 本稿では漁業地域 を社会経済的に分析するための視角である「生産 者間関係」（山内, 2004）に注目して論を進めたい。 山内は, 漁業者とそれを取り巻く様々な人々との 関係性は時代を通して変化し，これが地域の変動 にも大きな影響を与えると主張した。すなわち生 産者間関係とは，漁業地域の経済的な変化とその 地域に打いて各経営体の経営を担ら生産者の相互 関係を見直す分析視角であるといえる。

以上を踏まえて, 本稿では愛知県西尾市一色町 の養鰻産地を事例に, 戦後に扮ける養鰻産地の経 済的な変化を, 養鰻経営体の経営状況および生産 者間の関係性に焦点を当てて分析する。後述する

2) 地理学では自然条件に注目した研究が, 経済的な研究に先立っておこなわれた。例えば, 笠井 (1967), 新井 (1976), 山本潘か（1980）は，いずれも養鰻業の成立と河川水や地下水の状況との関係について報告している。

3) 種苗価格の高騰を引き起こす種苗採捕量の減少には, 高度経済成長期以降に顕著となったウナギの生息環境の悪 化が関わっているとされる（海部, 2016）。 
ように，一色町の養鰻業は高度経済成長期に生産 基盤に関わる制度の整備と生産技術の革新が図ら れ, 生産量を増加させた。そして, これらが生産 活動にも大きく影響してきた。その点からも，同 町は本稿の目的を達成するのにふさわしいと考光 られる。

\section{2 事例地域の概要}

一色町は，矢作川河口部の三角州地帯に位置し, 三河湾に面している（第1図）。沿岸部には低平 な湿地帯が卓越している（一色町史編さん委員会, 1970)。2011年, 当町は近隣の吉良町, 幡豆町と ともに西尾市に編入され，行政区としては現在， 西尾市一色町となっている。
当町は，小学校の校区をもとに，東部地区，南 部地区，西部地区，中部地区に分かれている（第 1 図)。東部地区は国道247号線より南側の地区で, 一色らなぎ漁業協同組合の資料によると，2013年 現在，全103の養鰻経営体のらち64経営体が集中 している。南部地区は1908年に竣工した農業用水 路である一色悪水路の東側に位置し，18の経営体 がある。西部地区は国道247号線並びに一色悪水路 より西側に位置し，21経営体が存在する。それに 対し，主として住宅地の広がる中部地区では，養 鰻業は招こなわ玌ていない。な扐，同資料による と, 一色町の2013年の養鰻生産量は $2,350 t$ であった。 これは, 都道府県別生産量で第 2 位 ${ }^{4)}$ を誇る愛知県 の総生産量（3,140t）の打よそ4 分の 3 にあたる。

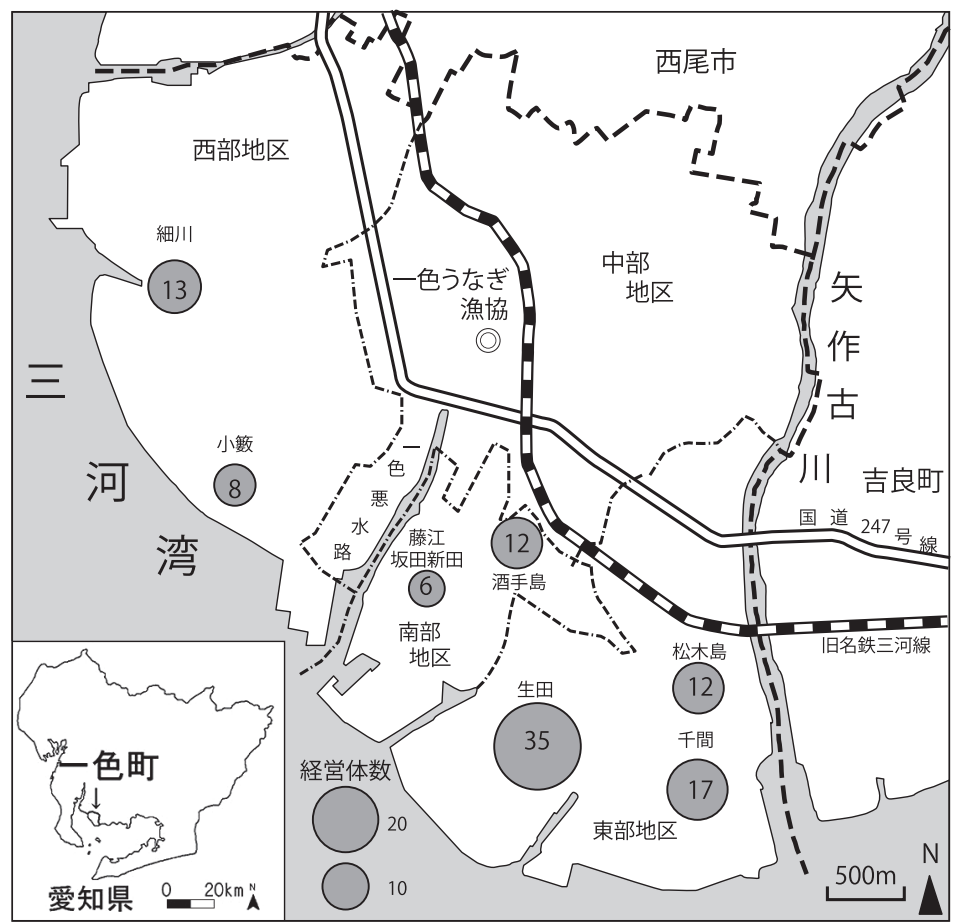

第 1 図 大字別の養鰻経営体数（2013年）

Figure 1. Number of management bodies by district (2013)

資料：一色らなぎ漁業協同組合資料

4) 2013年の国内の養鰻生産量は, 『漁業・養殖業生産統計年報』によると $14,204 \mathrm{t}$ であった。都道府県別にみると, 1 位が鹿児島県 $(5,747 \mathrm{t}) ， 2$ 位が愛知県 $(3,140 \mathrm{t}) ， 3$ 位が宮崎県（2,840t），4 位が静岡県（1,396t）であった。 これら 4 県が全国生産量の $90 \%$ 以上を占めている。 
現地調査は, 生産者への聞きとり, 生産に関わ る諸活動の観察を中心に，2013年 4 月から 2014 年 9 月にかけて集中的に実施し，その後も同様の 手法で2015年に追加調査を扣こなった。

\section{II 一色町における養鰻業の展開}

\section{1 戦後における生産基盤の整備}

一色町に打ける養鰻業の開始は，1894年に幡 豆郡一色町に設立された愛知県水産試験場での 試験的養殖 ${ }^{5}$ にまでさかのぼる（一色町編, 1999）。 1902年に同試験場が名古屋市へ移転したことに 伴って, 試験場が保有していた複数の養鰻池が地 元住民に払い下げられた。これが契機となり，民 間による養鰻業が本格的にはじまった占。ウナギ の需要が全国的に高まった大正期には, 養鰻池が 増設され, 生産量は増大した(増井, 1978)。しかし， 昭和期に入り第二次世界大戦がはじまると統制経 済が敷かれ，生産は一時的に休止した。

戦後, 統制経済が解かれ, ウナギの需要が徐々 に高まるにつれて, 全国に点在する養鰻産地は復 興を果たしていった。一方，一色町では，当時， リ養殖業と養鰻業を併営する零細な生産者が大半 を占めて打り, 彼らはノリ養殖に重点を置いてい たため, 養鰻業の復興は他の産地に比して遅れた (増井, 1999)。

養鰻業が本格的に復興するのは, 1960年代のこ とである。直接的な契機は, 1953年の台風13号 と1959年の伊勢湾台風による被害からの復興で あった（一色町誌編さん委員会編, 1970)。2つの 台風により，江戸時代の干拓事業によって開発さ れた東部, 南部, 西部 3 地区の水田の多くが, 洪 水と高潮による被害を被った。多くの農家は, こ
れによって稲作を維持することが困難となり，農 業からの転換を余儀なくされた。その結果として, 低湿地に打いて子経営可能な養鰻業が選択され, 廃水田を養鰻池へと切り替える動きが生じたので ある。これ以降, 制度面の整備, 並びに養鰻業成 立のための 3 要素である水源・種苗・饂料の確保 を通して, 生産基盤が順次整備されていった（第 1 表)。

制度面に関しては, 漁業協同組合（以下漁協と する）の設立および, 養鰻振興地域の指定が挙げ られる。1962年には, 西三河養殖漁業協同組合 (西 三河養殖漁協 $)^{7)}$ が設立された。各経営体は養殖 に必要な資材を共同で購入できるょらになり，生 産の安定化がはかられた。1967年には, 前述し た一色悪水路と名古屋鉄道三河線とに囲をれた地 域が養鰻振興地域に指定された。これは一色町が 主導した政策で, 経営体を一部の地域に集積させ る, いわば養鰻生産団地の建設であった（塚本, 2014）。こらして, 養鰻池が市街地から分離され, 餌料や用水による市民生活への悪臭被害が回避さ れることとなった。

水源の確保に関しては, 養鰻専用水道の敷設が 各経営体への池水供給を目的として1962年より開 始された。それまで養鰻業には, 矢作古川から取 水した農業用水が利用されていたが, 農業者と養 鰻経営体との間で農薬混入の問題をめぐって頻繁 に紛争が生じていた。こうした紛争を回避し,な おかつ養殖に適した良質な水を供給することを目 的として, 漁協と町が主導して養鰻専用水道の敷 設を進めたのである。その後, 両者は養鰻振興地 域を指定して経営体を集積させるとともに，1969 年の農林省による内水面養殖主産地形成事業の補 助を受けることで, 短期間のうちに多数の経営体

5)この時には, 池の構造不良が原因となり, 大雨の際に池があふれウナギが逃げ出したり, 冬期にウナギが越冬で きず大量に死隇したりするなどした結果，失敗に終わっている。

6) 1904 (明治37）年には地元の篤志家である徳倉六兵衛と徳倉広吉が 21 ha の池を造成し, 大規模な養鰻業を開始し た（一色町誌編さん委員会編, 1970)。

7) 西三河養殖漁業協同組合は, 1992年に一色らなぎ漁業協同組合に改称された。 
への配水を達成した。現在では, 町域の全経営体 がこの配水システムを利用している。

種苗の確保に関しては, 複数の供給先を獲得し たことが挙げられる。一色町の経営体と産地問屋 は，地元で採捕された種苗のみでは不足するため， 戦前より九州南部，本州西部，関東地方から種苗 を移入していた ${ }^{8)}$ 。しかし1960年代, 種苗から成 鰻までの一貫生産を和こなった方が高収入を得ら れるといら理由から，それまで供給元であった各 地に扔いても養鰻業が開始された。一色町の経営 体と産地問屋もこの影響を受け，種苗の入手に際
して支障が出るようになった。そこで, 両者は国 内にとどまらず，当時十分に採捕することができ た台湾・中国からも種苗を輸入して, 安定的に確 保できる体制を整えたのであった。

最後に餌料の確保に関しては, 配合餌料の登場 が大きく貢献した。戦後, 慨料には地元の漁業者 が三河湾で漁獲した鮮魚 ${ }^{9)}$ が主に用いられていた (増井, 1978)。しかし，鮮魚は長期間にわたる保 存が困難なら光，残㳯が池底に沈殿して池水を污 染してしまらため，これを除去しなければならず， 作業に手間がかかっていたといら。こ机に対して，

第 1 表 一色町における養鰻業の生産基盤整備と養鰻業界の歴史

Table 1. History of the improvement of eel production in Isshiki town and Japanese eel industry

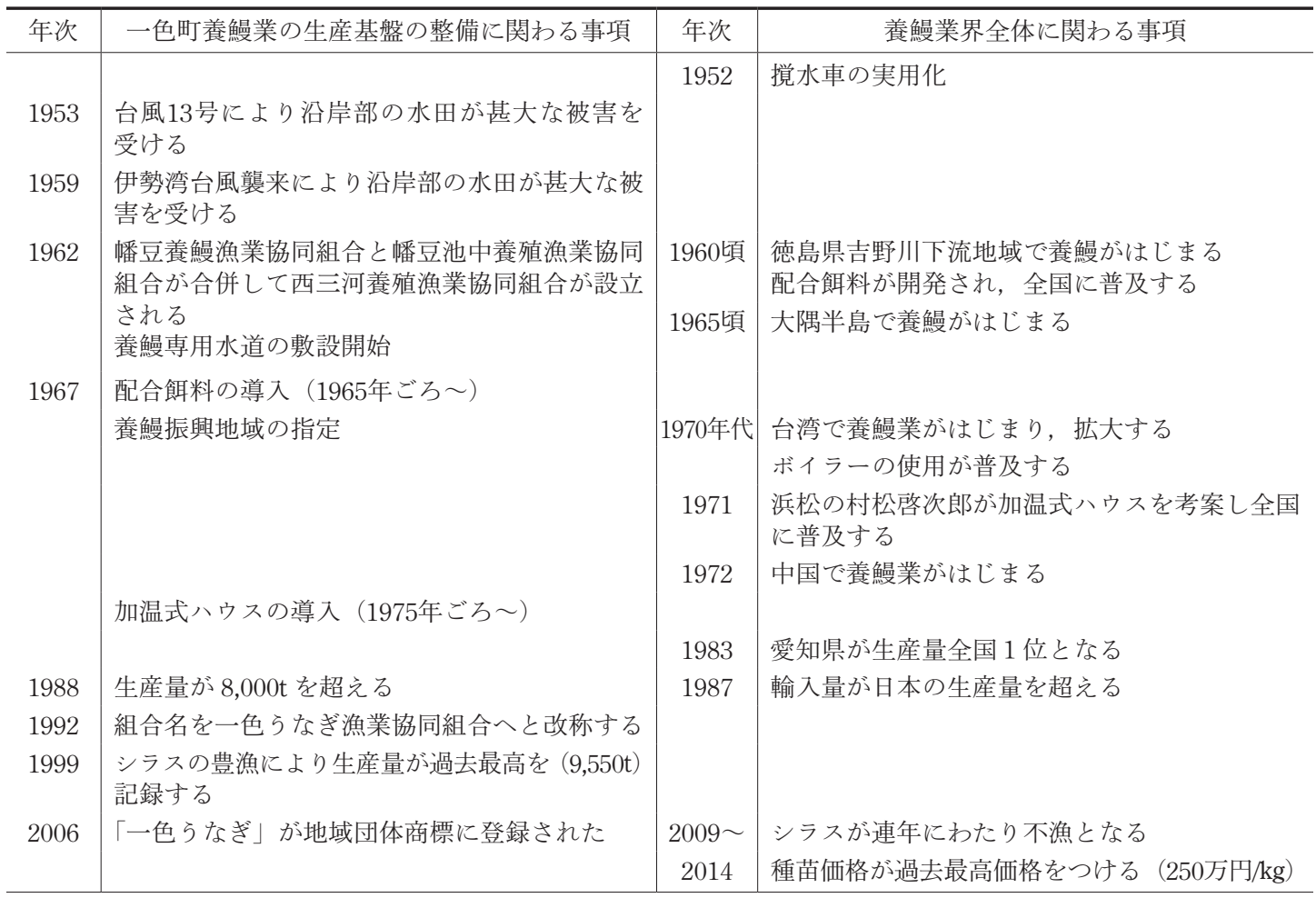

資料：『一色町誌』，漁協資料，生産者への聞きとり調査，白・佐野 (2006)，増井 (2013)，静岡新聞社・南日本新 聞社・宮崎日日新聞社編（2016）

8) 一色町誌編さん委員会編（1970）によると，当時の種苗供給先ごとの供給割合は，地元産が $30 \%$ ，九州と関東が それぞれ20\%, 本州中部，本州西部，四国がそれぞれ10\%であった。すなわち，一色町で使用されていた種苗の 70\%を他地域産のものが占めていたのである。ただし，外国産の種苗の使用に関しては記録がなく，1960年代は 依然として国内からの供給に限られていたものとみられる。

9) 東海地方では明治期から昭和初期にかけて, 飭料として養虫業の副産物であるサナギが用いられていた。この地 方では養虫業が盛んであり，入手が容易であった（増井, 1999）。 
1960年代に開発された配合䭒料は腐敗しにくく, 長期保存も容易であった。さらに水面に浮くタイ プのものがその後に開発されると, 残涬処理の時 間がより短縮化された。こうして配合餌料は各経 営体に普及し ${ }^{10)}$, 餌料の安定的な確保と作業の省 力化に貢献したのである。

\section{2 加温式ハウスの導入とその後の経済状況の変化}

一色町に打ける養鰻業の戦後復興は, 前節でみ てきたよらに生産基盤が整備されることで達成さ れたが, 生産量のさらなる増加に重要な役割を果 したのは，加温式八ウスの導入・普及であった。 加温式八ウスは，池全体をビニールハウスで覆い， 池水の外気との接触を防ぐことで，水温を人工的 に調節できるようにした施設である。八ウスで池 全体を覆わなければならないため，池面積を拡大 するのには不向きで， 1 池当たりの面積は扮括む ね 10a 以下となる。

加温式八ウスの導入以前では， 1 池当たり $20 \mathrm{a}$ 〜30a の露地池（和久田, 1959）で生産がおこな われていた。露地池では直射日光を遮るものがな いら光, 水を冷却する装置も当時は存在せず, 水 温調節がきわめて困難であった。そのため，夏期 には水温が上昇するにつれて池中の酸素濃度が低 下してしまい，生産者は酸欠によるウナギの大量 死を警戒しなければならなかった ${ }^{11)}$ 。ひれ対し て加温式八ウスでは，天井部に設けた換気扇を使 用してハウス内の熱気を外部へ放出するとともに, 水の供給量を増やすなどして水温を低下させるこ とが可能となった（大塚, 1996）。一方，冬期には 露地池では水温が低下寸るため, ウナギは冬眠し てしまい，摂餌しなくなる。これにより成長が遅れ， 種苗の池入れから成鰻の出荷までには約 2 年を要
していた。加温式ハウスでは，水の供給量を少な くしたり，ボイラーを焚いたりして水温の低下を 防ぐ措置がとられた。こうしてウナギは冬眠せず， 冬期でも摂餌するようなったことで，成鰻までの 養成期間が約200日にまで縮減した（廣瀬, 2001）。

こうした特徴をもつ加温式ハウスは，一色町に は1970年代前半に導入され，その生産性の高さ から急速に普及していった。これは，東部地区大 字生田に持ける養鰻池の状況の变化から女読及取 れる（第 2 図）。すなわち，1977年には大小合わ せて露地池が154か所，加温式八ウス型の池が44 か所存在していたが，1987年には露地池が87か 所へ減少する一方で, 加温式八ウス型の池は 102 か所と10年間でおよそ2.5倍になったのである。

加温式八ウスの急速な普及は, 一色町の生産形 態も変化させた。露地池が使用されていた時代に は，上記のよらに種苗から成鰻までの養成期間が 約 2 年であった。これに対して, 各経営体は当時, 1 年に複数回種苗の池入れを打こない, 約 $40 \mathrm{~g}$ に 成長したものをそのまま浜名湖地区や豊橋地区な ぞ他の産地へ販売していた ${ }^{12)}$ 。すなわち，池の回 転率を高めて 1 年間のらちに複数回出荷すること で，彼らは利益を得ていたのである。しかし，そ の後に加温式八ウスが導入され, 成鰻までの養成 期間が 200 日と大幅に短縮したことで，このよう な生産形態は不要となり, 多くの経営体はより高 值で取引できる成鰻までの生産に転換していっ た。さらに, 出荷の中心が成鰻となったことで, 一色町の生産量は1978年の $2,987 \mathrm{t}$ から1990年に は9,100tへと増加した（第 3 図）。以上のように, 加温式八ウスはウナギの致死率の低下，養成期間 の短縮化だけでなく，生産量の増大にも貢献した のであった。

10) 1968年には，一色町の全投餌量における鮮魚の割合は約 $20 \%$ そどまっており，すでに活とんどの経営体で配 合餌料が使用されていたという（一色町誌編さん委員会編, 1970）。

11）擋水車が水中の酸素濃度の低下を防ぐことを目的として，1952年頃から実用化され普及した（増井, 2013）。しかし， それでも完全に大量死のリスクを抑えることは困難であった。

12)この養殖形態は，出荷していたウナギのサイズから一般に養中生産と呼ばれた。 


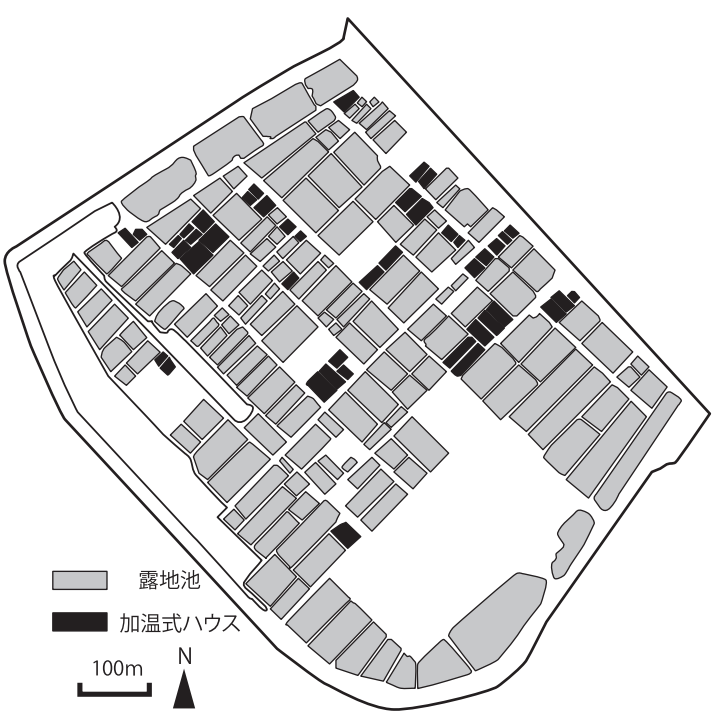

1977 年

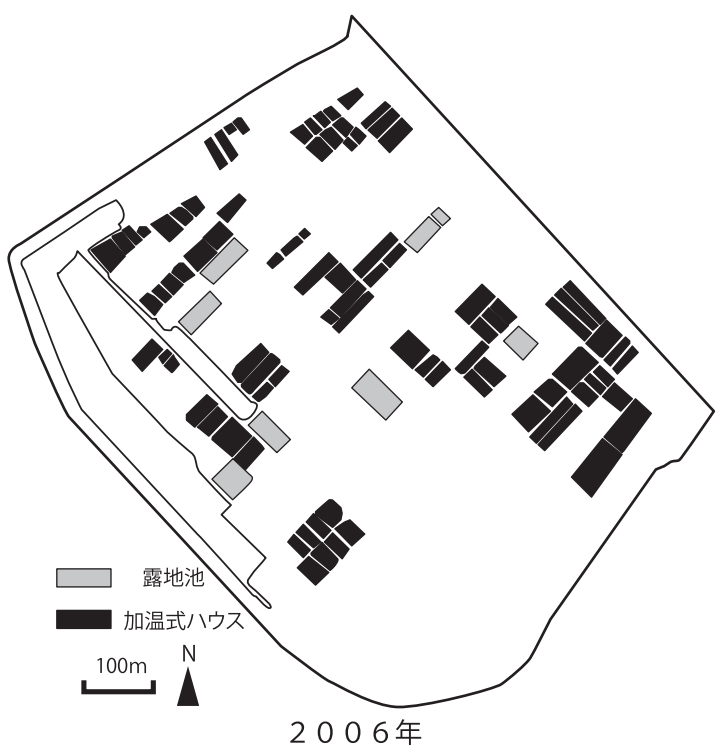

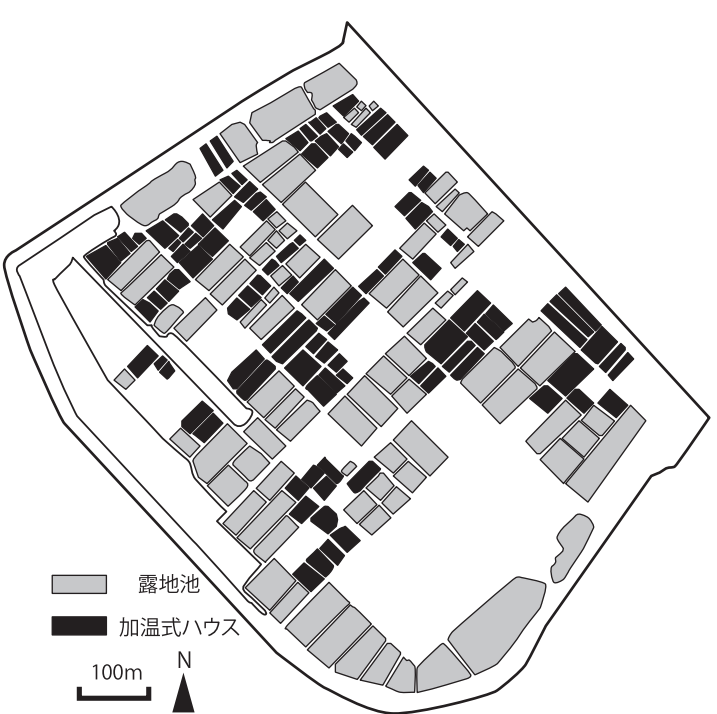

1987 年

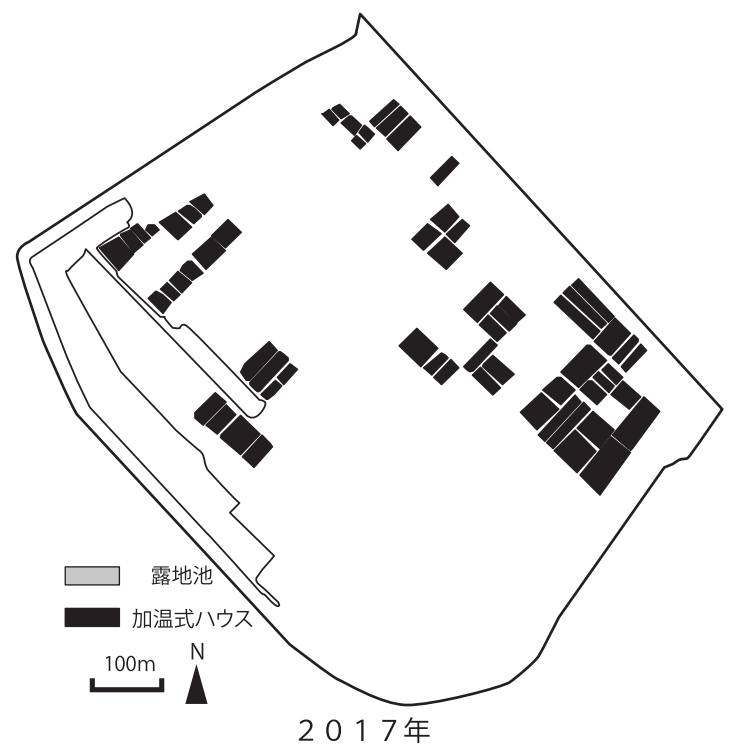

第 2 図 大字生田に抢ける養鰻池数の変化

Figure 2. Changes of the number of ponds in Ikuta district

注 $1 ：$ 1977年から2006年までは航空写真から作図したため, 実際の使用状況は不明。 注 $2 ： 2017$ 年は現地調査に基づいて作図したため，使用状況が反映されている。

資料: 国土地理院航空写真, 現地調査

\section{III 経営状況と集出荷作業の特徵}

\section{1 養鰻経営体の経営状況}

3 条件の確保・整備と加温式八ウスの導入は他 地域でも同様に進行したため，一色町は1980年代
以降, 国内执よび海外の産地との価格競争に巻き 込まれていった ${ }^{13)}$ 。さらに2010年以降は, 採捕量 の減少に伴い種苗価格が高騰し ${ }^{14)} ， 1 \mathrm{~kg}$ 当たり 50 万円以上での取引が常態化した（第 4 図）。漁協 の資料と各種統計によると，これらの影響を受け 


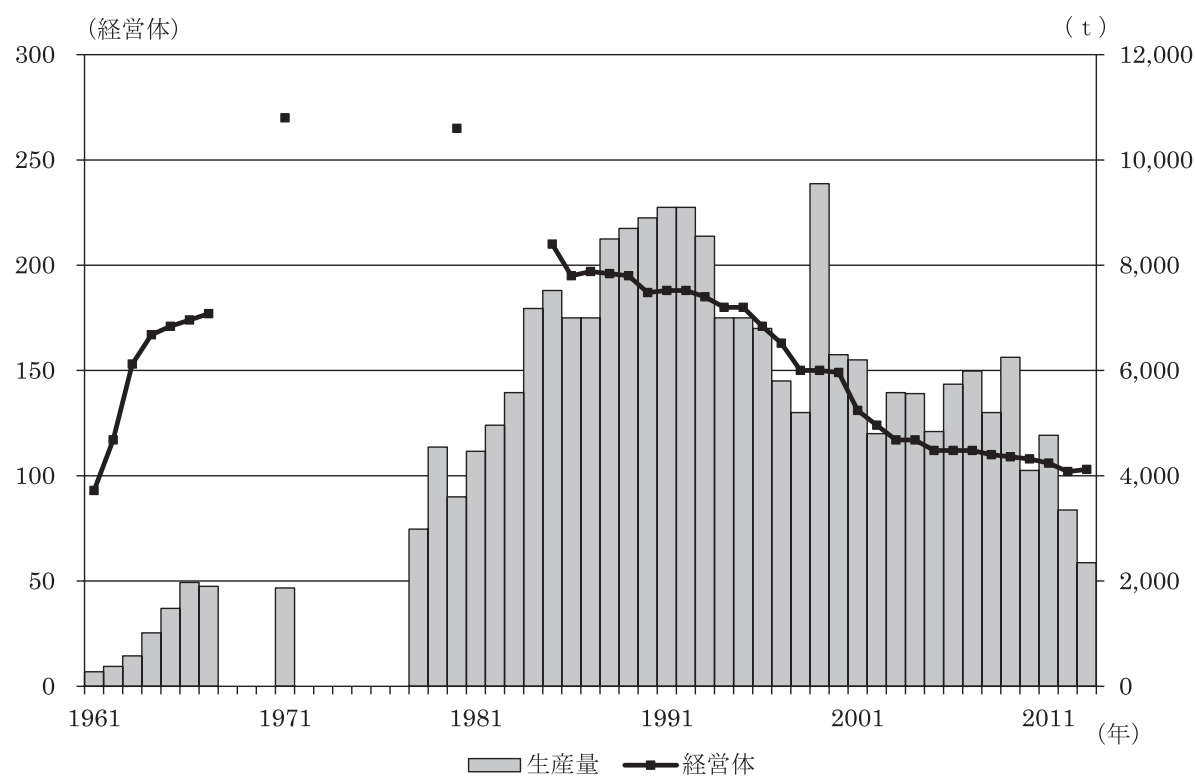

第 3 図 一色町の養鰻経営体数と養鰻生産量の推移

Figure 3. Changes of number of management bodies and eel productions in Isshiki town

注 1 : 1968年から1985年までの経営体数に関しては欠落がある。

注 2 : 1967年から1977年までの生産量に関しては欠落がある。

資料 :『一色町史』(1961年～1967年)，一色らなぎ漁協資料（1962年～2013年)，『愛知県統計年鑑』 （1962年～2013年）

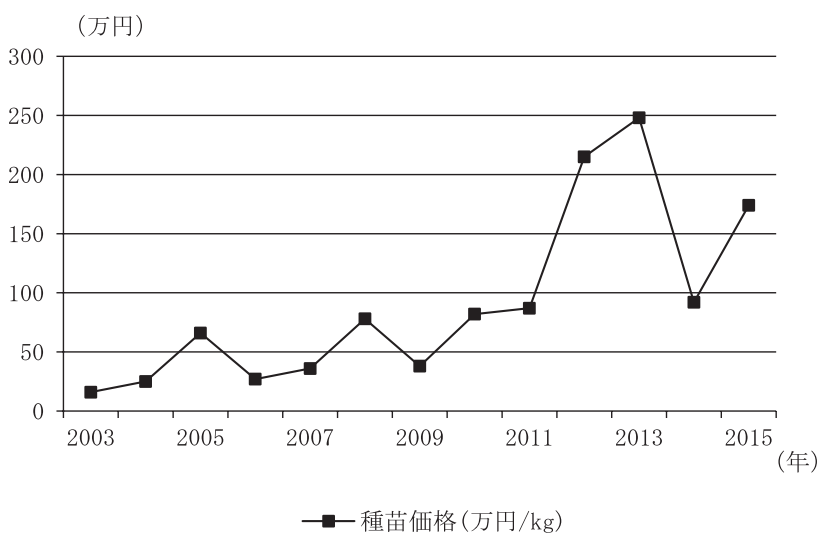

第 4 図 2003年以降のシラス価格の変化

Figure 4. Changes of seedling eel price after 2003

資料：農林水産省 HP（http://www.jfa.maff.go.jp/j/saibai/unagi.html，2017年 5 月28日最終閲覧）

13）日本の産地が1980年代に台湾および中国の産地との市場競争に巻き込まれていった過程については，増井（2013） に詳しい。当時すでに種苗不足に陥っていた日本とは異なって，シラスを大量に採捕できた台湾および中国中南 部では, 日本のウナギ市場に参入することを目論み, 国内の養鰻業を拡大し, 成鰻を輸出するよらになった。こ れらの地域では, 気候が温暖であり, 露地池でもウナギを十分に責殖できたため, 生産コストを低く抑えること ができた。こらした過程を経て, 安価な外国産の成鰻が日本に大量に輸入され, 国内での成鰻価格が崩壊するこ ととなった。 
て1980年に町内に265あった養鰻経営体は大きく 減少し，2013年には103経営体となっている。ま た生産量もピーク時（1990年）の 9,100t $\mathrm{t}^{15)}$ から, 2013年には 2,350tへと減少している（第 3 図）。 このような養鰻経営を取り巻く状況の悪化は，養 鰻池が広がる景観の変化からも読み取れる。前掲 した第 2 図によると，1987年に102か所あった加 温式八ウス型の池は, 経営体の廃業に伴う放棄や 埋め立てによって，2006年には87か所，2017年 には63か所へと減少した。30年間で, 約 4 割の 養鰻池が消滅したのであった。

一色町の養鰻経営体のなかにも, 主として種苗 価格の高騰によって，経営を維持できなくなり， 休業中であるものが多い。一色うなぎ漁協への聞 きとりによると，先述した103経営体のらち実際 に経営を続けているのは約70経営体のみであると いら。そこで, これら経営を維持している約70経 営体の経営状況を解明するために, 全経営体のら ちから33経営体の経営主に聞きとりを扎こなった。 第 2 表は，その結果をまとめたものである。なお 漁協から提供された資料によると，2013年の組合 員数は 238 人，八ウス池面積は $7,100 \mathrm{a}$ であった。

経営形態に関しては, 30経営体が家族経営で あった。 1 経営体当たりの労働力の人数は， 2.8 人 となっていた。労働力の構成をみると, 明らかに できた 27 経営体で，男性が経営に関わるすべての 作業を担ら経営主をつとめていた。また，27経営 体のらち22経営体で女性の従事者がみられた。彼 女たちの多くは，世帯主の妻もしくは母親であっ た ${ }^{16)}$ 。したがって, 一色町の養鰻経営では, 世帯 主である男性とその家族を労働力とする小規模な 家族経営が一般的であるといえる。
家族で経営する 30 経営体以外の 3 経営体の5 ち，2 経営体が産地問屋， 1 経営体が一色らなぎ 漁協によって経営されていた。通常, 各経営体が 養成した成鰻は町内に 10 業者ある産地問屋，も しくは一色うなぎ漁協に出荷される。産地問屋は, 成鰻の仲買業者として生産者と消費者とを取り結 び，需給を調整する立場にあるが，それにとどま らず生産・加工事業に着手する場合がある。自ら で生産から出荷まで报こならことで，各経営体か らの仕入れ量が減少したときでも, 出荷の不足分 を補えるようになるからである。現在，町内では 4 業者が生産事業を和こなっている。産地問屋に よる生産事業への参入は, 生産量が減少するなか で，今後も増えると考光られる。

次に各経営体が所有する池面積についてみると, 1 経営体当たりの平均は $77 \mathrm{a}$ であったが，200a から 37a まで経営体ごとに差がみられた。しかし， 各経営体は必ずしも所有する池のすべてを使用し ているわけではない。第 2 表によると，池の稼働 率を $100 \%$ と回答したのはわずか 8 経営体であり， 全経営体の平均稼働率は64\%にとどまっていた。 稼働率が低水準で推移していることにも，2010年 以降引き続くシラスの不漁による種苗価格の高騰 が関係している。すなわち, 各経営体では自らの 経営規模に適した量の種苗を購入できず，池を満 足に稼動させられないのである。したがって，生 産実績は当然ながら所有する池面積よりも稼働面 積に規定されている。

\section{2 養殖方式と生産暦}

以上のような経営状沉のもと，各経営体は，短 年養殖と周年養殖という 2 種類の養殖方式を選択

14) 種苗の不漁は2010年から続いており，2013年度（2012年冬から2013年初春にかけて）の仕入れ值は2004年のお よそ10倍に当たる $1 \mathrm{~kg}$ 当たり 260～270万円であった（朝日新聞2013年 5 月 13 日）。

15) 生産量が過去最高を記録したのは1999年の 9,550t であったが，これは1998年に大量の種苗が突発的に採捕され た結果生じたものである。したがって，本稿では1999年ではなく1990年を生産量のピークとした。

16）彼女たちの作業内容は，投饂から集出荷作業の手伝い，八ウスのビニールの張り替えまで多岐にわたっている。 家族内の女性が，一色町の養鰻業を支える重要な労働力となっている。 
第 2 表 養鰻経営体の経営状況（2013年）

Table 2. Conditions of management bodies of eel production in study area (2013)

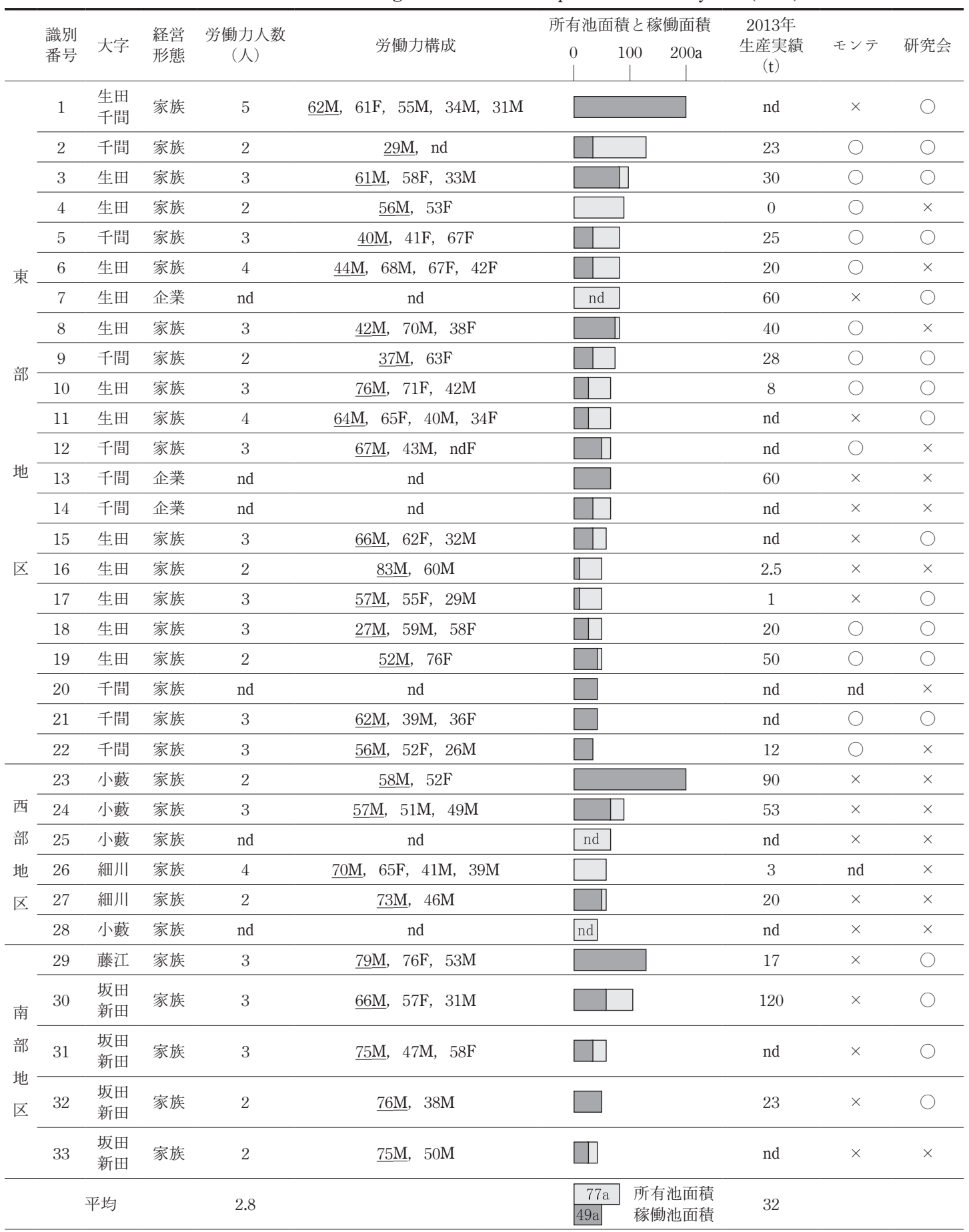

注 1 : 労働力人数, 労働力構成, 2013 年生産実績, モンテの欄の「nd」はデータがないことを示す。所有池面積と稼働池面積の「nd」 に関しては, 稼働池面積の詳細が不明であることを表す。

注 2 : 労衝力構成の数字は各労働力の年齢， $\mathrm{M}$ は男性， $\mathrm{F}$ は女性，下線を付した者は経営主である。

注 3 : 抽出式の調査であるため, どの経営体同士が同一モンテを組織しているかは明らかでない。

資料：経営体への聞きとり調査 
しながら生産をおこなっている。短年養殖とは, 種苗の池入れから200日程度で成鰻にまで養成し 出荷する方式である。経営主は, 給餌量と水温を こまかく調節することによってウナギの生育速度 を管理し，成鰻価格が一年のうちで最高となる土 用の丑の時期に出荷量が最大になるよらにする。 一方，周年養殖は種苗を池入れしたのち約 1 年か ら 2 年かけて出荷サイズにまで養成し, 年間を通 じて出荷する方式である。周年養殖の採用によっ て各経営体は，流通量が全国的に少なくなり高価 格での取引が期待される冬期にも出荷できる。そ のら光荷の時期を分散させることができるた め，年間を通じて安定的に収入が得られる。ただ し，漁協関係者への聞きとりによれば，一色町の ほとんどの経営体が短年養殖を志向しているとい ら。これは, 種苗の池入れから養成, 出荷までの 作業の期間を短くできるらえに, 多くの成鰻を年 間で最も価格が高くなる土用の丑の時期に集中し て出荷するため，高収入につながるからである。

そこで，短年養殖の年間の作業工程を第 5 図に 示した。11月から 1 月にかけての種苗の購入か ら, 翌年10月から11月にかけての八ウスの整備
にいたるまでが一連の工程である。特に， 3 月か ら8月にかけて扣こなわれる成鰻の養成において は, 出荷時期を調整するために, 経営主が養成期 間を管理しなければならず，経験に基づいた高度 な知識と技術が求められる ${ }^{17)}$ 。これに対して，5 月から 9 月にかけておこなわれる, 成鰻を池から 収獲し出荷する作業（以下，これを集出荷作業と よぶ）では，次節で述べるように特別な知識や技 術は必要としない。しかし, 複数の生産者との協 力など労働力を一時的に確保しなければならなら ず，当町の養鰻業で一般的な小規模な家族経営体 では，労働力に関する問題が発生することとなる。

\section{3 集出荷作業の種類とその内容}

集出荷作業には，2 種類の方法がある。ひとつ は, 複数の人々が協力して池全体を地曳網で囲い ウナギを収獲する方法であり, 露地池が使用され ていた時代から抗こなれている。この方法では， ウナギが網の目合より細い場合には網をすり抜け る。そのため, 目合の異なる網を使い分けること で，ある程度ウナギを体長ごとに収獲することが できる。

\begin{tabular}{|c|c|c|c|c|c|c|c|c|c|c|c|}
\hline & 9 & 10 & 11 & 12 & 1 & 2 & 3 & 4 & 5 & 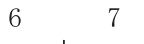 & 8月 \\
\hline シラス購入 & & & & & & & & & & 作業期間 & \\
\hline シラス養成 & & & & & & & & & & 繁忙期 & \\
\hline シラス池入れ & & & & & & & & & & & \\
\hline 成鰻養成 & & & & & & & & & & & \\
\hline 集出荷作業 & & & & & & & & & & & \\
\hline ハウスの整備 & & & & & & & & & & & \\
\hline
\end{tabular}

第 5 図 短年養殖の生産暦 (2010年ごろ)

Figure 5. Production calendar of single-year farming

注 1 : 繁忙期は作業が集中する時期をさす。

注 2 : 表記法はウナギ年度（前年 9 月から当該年 8 月まで）にしたがっている。

資料：生産者への聞きとり調査

17) 生産者は, 責成期間を管理するために, ウナギの生育度を常に確認し日々の気象条件に応じて池水の温度, 餌料 の種類と配合量, 給餌量などを調整しなければならない。短年養殖を扎こなら場合には, このような個別経営体 の技術レベルが大きく関係している。 
しかし，地曳網を使用する方法では，小規模な 経営体では多数の労働力を確保することが求めら れる。これに対して，一色町では2000年ごろか ら作業の省力化を目的とした新たな方法が現れる ようになった。それが，池中のウナギを機械式の ポンプで水ごと吸い上げる方法である。この方法 の導入によって，複数の生産者で池を囲い込む必 要がなくなり，家族労働力のみでも作業ができる ようになった。収獲後には，各経営体が保有する コンクリートで作られた作業用の池で，ウナギは 体長ごとに選別されて出荷される。

ただし，聞きとりをした経営体のらち，ポンプ による収獲を実施していたのは 3 経営体のみで あった。残りの30経営体は，その費用負担の大 きさを敬遠して，現在でも地曳網による収獲を抒 こなっていた。漁協関係者への聞きとりによると， ポンプによる収獲では，選別作業用の池が養鰻池 とは別に必要となり，それに多額の資金を投下し なければならない。一色町では小規模な家族経営 体が大半を占めることもあり，経費がより少ない 従来扮こなわれてきた地曳網による収獲を好む傾 向がみられるのである ${ }^{18)}$

そこで，当町で主流となっている地曳網による 収獲の状況を明らかにするために，2013年 9 月 12 日に第 2 表の東部地区の経営体 No.9 が拈こなっ た集出荷作業を観察した。当日の参加者は, 経営 主とその母親, 他経営体の経営主 3 名, 餌料供給 業者 1 名の合計 6 名であった（第 6 図）。作業は, 午前 8 時30分から始まった。

はじめに参加者全員が網をもちながら，20m×30m の養鰻池の壁面に沿らょうに移動し，池全体を網 で囲ら。次に，ウナギが十分に捕獲できたのを 確認して，全員が曳網する。捕獲されたウナギ は，池の端に設えられた簡素な生筫へと一旦放さ れる。次に, 1名が池の外からプラスチック製

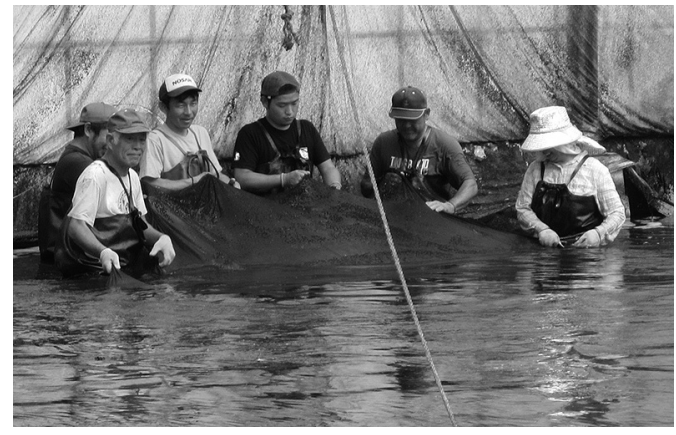

第 6 図 集出荷作業

Figure 6. Pick-up and Shipping activities in pond 作業者は左から, 手前が飭料供給業者, 奥が経営主, 手 伝い関係にある生産者, モンテの生産者 2 名, 経営主 の母親となっている。

資料 : No.9 の養鰻池にて 2013 年 9 月 12 日筆者撮影

のカゴ (入口直径 $40 \mathrm{~cm}$, 胴部直径 $70 \mathrm{~cm}$, 高さ $30 \mathrm{~cm}$ ）を池中の者へ渡し，それを受け取った 2 名が次々とカゴの中へウナギを入れていく。カゴ の重量は，このとき 1 個当たり約 $40 \mathrm{~kg}$ にも及ぶ。 その後, カゴは出荷作業がはじまるまで池中に留 め置かれる。

池中での作業が終了すると, カゴは 1 つずつ池 から揚げられる。その際, 全員で協力してウナギ の入ったカゴを氷水にさらす，「しめ」とよばれ る作業が括こなわれる。これを経ることで，ウナ ギが仮死状態となりつかみやすくなるため, 出荷 後に荷受け側が扣こなら体長ごとの選別作業が容 易になる。「しめ」を経たカゴは，その後順次卜 ラックへと積み込まれていく。すべての作業は, 午前11時に終了した。なお, 当日の出荷量はカゴ 61個，重量にして約 2.4t であった。

以上のように，地曳網を使用する集出荷作業で は, 労働力の不足が生じるため複数名による協業 がなされる。そのため, 集出荷作業をおこならに は経営主間での手伝い関係を構築することが求め られる。そこで, 次章では, 当町に存在するこう

18）ポンプによる収獲は, ウナギにストレスがかかりやすいといら。資本が必要ならえ, このようなマイナスのイメー ジがあることから，この方法は積極的に採用されていないと考えられる。 


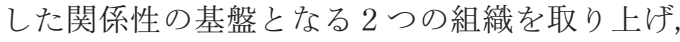
その特徴について考察する。

\section{IV 手伝い関係の基盤となる組織}

\section{1 モンテ}

手伝い関係の基盤となる組織として，はじめに 「モンテ」がある。これは，無償による労働の貸 借といら性格を有する経営主の集団を指す。1つ のモンテは通常, 地縁や血縁に基づいて 3,4 名 で構成される ${ }^{19)}$ 。また，各人が複数のモンテに属 することはない。それぞれの経営主は，家族労働 力のみで作業をおこならことが困難なときに，同 じモンテに属する者に手伝いを依頼する。特に, 加温式ハウスのビニールの張り替えや鉄骨の補修, さらに集出荷作業においてはモンテが貴重な労働 力となる。なお，手伝いを依頼された場合，必ず 作業に参加しなければならない。そのため, この 組織の拘束力は強いといえる。

聞きとりによるとモンテは, 露地池が使用され ていた1960年代以前には，一色町のほぼすべての 生産者の間で組織されていたという。これは, 露 地池 1 池の面積が 20a〜 30a に及び, 集出荷作業 に際して現在よりも多くの労㗢力を必要としたた めである。

しかし加温式ハウスが導入された1970年代以 降には，モンテの消滅が相次ぐこととなる。1 池 当たりの面積の縮小に伴い, 集出荷作業に際して, 露地池時代汪どの労働力は必要なくなり, 家族や 親族のみでも作業することが可能となったためで ある。さらに聞きとりによると，加温式八ウスの 建造費用や加温のための燃料費など新たな運転資
金の負担に耐兄られない経営体が，1970年代後 半から80年代にかけて相次いで廃業したことも 関係しているという（第 3 図）。経営主の離業に よって, モンテを脱退する者も増加し, 人員を確 保できないモンテは消滅していった。

モンテの組織化は現在, 東部地区の経営主が中 心となっている。第 2 表によると, いずれも東部 地区に所在する13経営体の経営主がモンテを組織 している。東部地区の大部分は前述したょうに, 養鰻振興地域に指定されて和り, 町内で最も経営 体が集積する地域である。また，地区割りは主と して小学校区を単位としていることから, 経営主 同土が同じ学校の卒業生である場合が多い。例光 ば, No.5 と No.9 の経営主は互いに小・中学校の 同空生であり，仕事の合間にも付近の養鰻池を訪 ねて世間話をしたり, 経営や養殖技術に関して会 話を交わしたりするなど，日常的に交流する機会 があるといら。さらに, No.8 や No.9 の経営主が 属するモンテのメンバーは，こうした交流を通じ て，自らが所属していたモンテが消滅した後にも， 別のモンテに加入できたという。このように経営 体が集積する東部地区では, 経営主がモンテを組 織しやすい環境が整っていたといえる。

\section{2 一色うなぎ研究会}

モンテの消滅がみられるなか,「一色らなぎ研 究会」（以下，らなぎ研究会とする）が新たな関 係性の形成に貢献している。これは，東部地区の 生産者が1968年に設立した私的な団体である。生 産者間での交流を通じて, 養鰻経営の安定化や養 殖技術の向上を促すことを目的として設立された。 一色らなぎ漁協の会議室にて開催される毎月の定

19）モンテは，農作業において共同労働を意味する「結」に相当する。生産者は日常会話のなかで「らちのモンテ では…」や「○○さんのところのモンテ」のように共同労働自体や共同労働を扔こなら集団を意味する言葉と して使用している。モンテの発祥については, 聞きとりによると, 養鰻業が隆盛する以前におこなわれていた, リ養殖業や農業にみられた共同労働の習慣が，養鰻業にも引き継がれたと考兄られるが，詳細は不明である。ま た，モンテといら呼称自体は，一般に弟子を意味する「門弟」が転叱したものと考兄られる。ただし，生産者の 間に師弟関係を確認することはできなかった。 
例会のほか，資源保護のための親ウナギの放流事 業，各種イベントにおける一色らなぎの $\mathrm{PR}$ 活動 など活動内容は多岐にわたっている。

漁協の資料によると，らなぎ研究会には2014年 の時点で35名の現役の生産者が加入している。そ のらち25名が東部地区に，10名が南部地区に池を 所有して抢り，西部地区の者はいなかった。聞き とりに挴いても, 加入者の存在を確認できた 17 経 営体のうち13経営体が東部地区に，4経営体が南 部地区に位置して和り, 加入者の特徵として地区 的な偏在がみられる (第 2 表)。この要因のひと つとして, 先述した東部地区の生産者間にみられ る活発な交流をあげることができる。2013年 9 月の定例会では, 10名の生産者が出席したが, こ のらちの 7 名が東部地区の生産者であった。彼ら はいずれも同会への加入の理由として，「仲間に すすめられたから」と回答していた ${ }^{20)}$ 。すなわち, それぞれの生産者は, 同会に加入する以前から交 流をもっていたわけであり，彼らはそのつながり を通じて加入したのであった。

さらに, らなぎ研究会の加入者の特徴として, 若手生産者が多いことがあげられる。上述の定 例会への参加者の年齢を集計したところ，平均は 37.7 歳であった ${ }^{21)}$ 。この数值は, 第 2 表にある経 営主の平均年齢を約 20 歳下回るものであり, 経営 主の跡継ぎにあたる世代が積極的に参加している 状況が読み取れる。このように，らなぎ研究会は 若手生産者の交流の場としても機能しているので ある。

それでは，モンテとうなぎ研究会を基盤とする 関係性は, 集出荷作業をめぐる手伝い関係の構築 に拉いて，どのような役割を果してきたのであ ろらか。次章では, 関係性の強固な経営体として No.9 を, 関係性の弱い経営体としてNo.27を事 例に，その実態について検討する。

\section{$\mathrm{V}$ 生産者間関係の変化の実態}

\section{1 関係性を重視する経営体一No.9 の事例一}

No.9 は, 東部地区にある 72a の加温式八ウス 型の養鰻池を所有する家族経営体である。現経営 主の父親が，高度経済成長期に操業を開始した。 現在では，37歳の経営主と63歳の母親の 2 名が 経営する。集出荷作業は, 家族労働力のみでは実 施できないため，モンテとらなぎ研究会を通じて 労働力が確保されている。以下では, No.9を中 心とした生産者間の関係性とその変化を, 経営主 からの聞きとりに基づき考察する。

はじめに，モンテを通じた関係性について検討 する。約 30 年前, 先代は東部地区に位置する 4 名の経営主とともにモンテを組織していた（第 7 図)。このらち，2名は廃業を機会にモンテから 脱退した。また，1名は加温式八ウスを造成して 以降, 家族のみで集出荷作業をおこなえるように なったため, 同じくモンテから脱退した。したがっ て，現在にいたるまでの長期間にわたって関係が 継続しているのは，1名のみといらことになる。

2014年現在, No.9 は東部地区の 2 名の生産者 (以下，A と B とする) とともにモンテを組織し ている。このらち養鰻池の隣接するA したNo.9 の父親の代から長期にわたり継続した 関係のある経営主である。他方 B は，2000年頃， 先代との交友関係をもとにして新たに加入してき た経営主である。これは，B が以前所属していた モンテの経営主が全員離業してしまい, 集出荷作 業時の労働力の確保を迫られたためである。No.9 の経営主は着業時から現在に至るまで, この 2 名 と組織するモンテから脱退せず, その関係を維持 してきた。当町でモンテの解消が進むなかにあっ ても，経営主が関係性を維持する背景には，以下 のような着業時の経験があった。

20) 残りの 3 人の加入理由は,「親にす寸められたから」,「情報交換のため」,「話し相手をつくるため」といらもの であった。

21) 参加者は全員が男性で, 最年少が29歳, 最年長が 47 歳であった。 
経営主は, 2003年に前職を辞し, 父親の手伝 いとして養鰻業をはじめた。当時, 種苗は現在の ように高価格で取引されて扔らず, 経営も安定し ていた。収入面でも前職と比べてよかったことか ら，彼は転職を決意したという。しかし，開始か ら数か月後に父親が急逝した。当時は, 着業して から間がなかったため, 経営主は餌料の配合方法 や水温の調節，集出荷作業の手順など基礎的な技 術を修得できて扣らず，廃業も考えたという。

このよらな経営危機において，モンテが大きな 役割を果たした。すなわち，同じモンテに属して

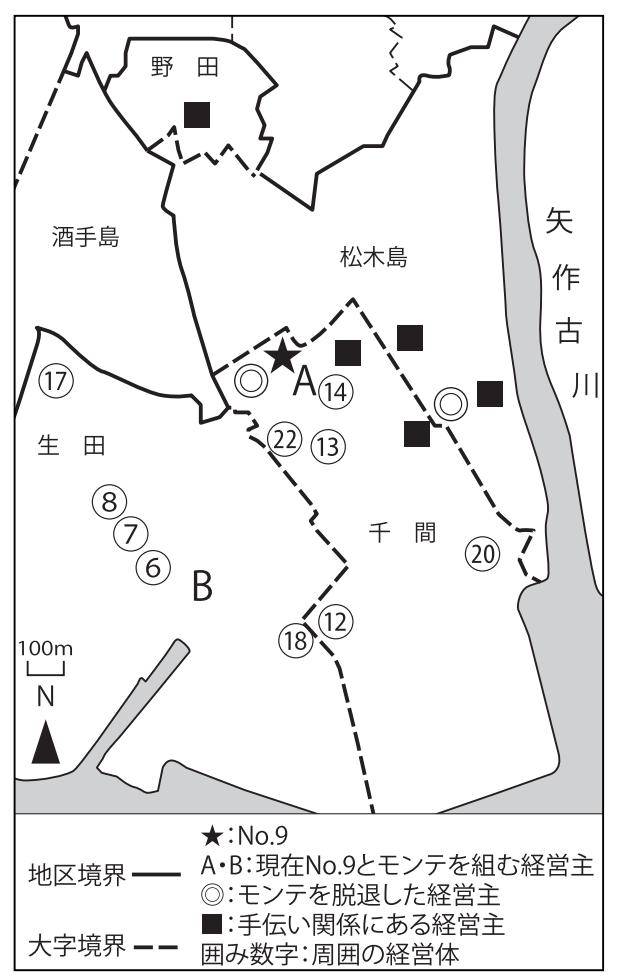

第 7 図 No.9 とその手伝い関係にある経営主の池の所 在地

Figure 7. Locations of ponds of No.9 and its assistants

注 1 : 丸囲久数字は，第 2 表の識別番号と対応する。

注 2 : 聞きとり調査を和こなった経営主のみを記載した。

注 3 : No.9 とかつてモンテの関係にあった 5 経営体の らち，2 経営体の久の位置を確認できた。

注 4 : 手伝い関係にある生産者 1 名の池の場所は特定 できなかった。

資料 : No.9への聞きとり調査
いた A と B が上記の養殖技術の全般を指導して くれたのであった。経営主は, 生産に関わるすべ てのことをこの時期に学んだと語って扮り, 両者 に対して深く恩義を感じているといら。それ以後, 彼らとの親密な関係は継続して拈り，たとえばA・ B のいずれかに急用ができたときなどには，彼ら の池をめぐり, 水車が稼動しているか, 水が正常 に供給されているかなどを確認することがあると いう。経営主はモンテの集出荷作業に打情労働 力確保の機能のみならず，こうした相互扶助的な 機能も重視しているのである。

しかしながら，No.9 は家族とモンテを合わせ ても 4 人分の労働力しか確保できず, 集出荷作業 に際しては，依然として労㗢力の不足が生じる。 そこで経営主は，らなぎ研究会を通じて形成され た人的関係も活用している。経営主は, 生産者仲 間をつくった方がよいといら父親の勧めで，2003 年の着業と同時にうなぎ研究会へ加入した。これ 以降, 定例会には毎回出席しており, 参加者との 関係を10年以上にわたって築いてきた。

現在，経営主は集出荷作業に際しては，自身の 池と近接した場所に池を有する 5 名の経営主にも 手伝いを依頼している（第 7 図）。5名のらち最 年少が 30 歳で, 最年長は49歳である。この手伝 い関係は，No.9 の経営主（37歳）と比較的年齢 が近い若手生産者によって組織されている。

モンテが強制的な労働の提供であったのに対し て、らなぎ研究会を通じた手伝いは強制されるも のではない。No.9 の経営主によると, 全員の年 齢が比較的近いことも作用して，それぞれの事情 によって手伝いの依頼は断れるという。また，手 伝いには 1 回ごとに賃金が支払わ机る。こうする ことによって，ある生産者の手伝う回数が多く なったとしても，不満は出ないという。このよう に，らなぎ研究会を通じた関係性はモンテとは異 なり，強制を伴わないより緩やかなものとなって いるのである。No.9 の経営主は，強制力を持つ が相互扶助的な機能も有するモンテによる関係と, 
集出荷作業の手伝いに特化した緩やかなつながり であるらなぎ研究会を通じた関係を組み合わせる ことによって，集出荷作業の労働力を確保してい るのである。

\section{2 新たな関係性を形成する経営体一No.27 の 事例一}

No.27は，西部地区に 60a の池を所有する家族経 営体である。現経営主の祖父は，1928年に 240a の養鰻池を造成して操業を開始した。現在は着業 から 3 代目にあたり，73歳の経営主と46歳の息子 の 2 名が経営している。No.9 とは異なり, No.27 は1980年代にモンテを解消した。また, 経営主 はらなぎ研究会を「東部地区の生産者の会」であ ると認識しており，これまで所属したことはない。 その一方で，生産者との関係性が乏しいなかでも， 地曳網を使用する集出荷作業が続けられている。 以下では, No.9 と同様に経営主の養鰻経営に関 する経験を振り返り，モンテの解消に至った経緯 と, 現在の労働力の確保について検討し, 生産者 間の関係性の変容を明らかにする。

経営主は, 1955年に中学を卒業し, 父親の手伝 いとして養鰻業を開始した。II で述べた1950年代 の 2 度にわたる台風の来襲によって, 複数の露地 池が壊れる被害を受けたが，経営主はそれを乗り 越光，高度経済成長期にはウナギ需要の伸長を背 景に養鰻池を次々と増やしていった。この時期に 得た利益を元手に, 彼は1976年からは加温式八 ウスの造成をはじめ, 拈よそ 3 年をかけて $240 \mathrm{a}$ あった露地池のうち 100a を転換した。その後も 増産を目指して，80年代にかけて加温式八ウス型 の池が建造された。第 8 図は，1977年から2017 年までの No.27 の養鰻池の変化を図示したもので ある。これによると，1977年には18か所の露地 池に対して加温式八ウス型の池は17か所であっ
たが，1987年には露地池が 9 か所，加温式八ウ ス型の池が27か所となっており，10年間で加温 式ハウスへの転換が急速に進んだことがわかる。

こうした積極的な加温式ハウスの造成は, モン テとの関係を変化させた。経営主は, 露地池を使 用していた1970年代前半までは，養鰻業を営む実 弟と近隣の生産者 3 名を加えた 4 名とともにモン テを組織し(第 9 図), これに加えて, 家族・親 族も動員して集出荷作業を拈こなっていた。しか し, 加温式八ウスが導入され，1池当たりの面積 が縮小したことにより，家族・親戚のみで作業に 当たれるようになった。こうした集出荷作業の省 力化によって, モンテが不要なものとなり, 経営 主はそこから脱退するにいたったのである。

しかし，2000年代後半に入ると，種苗価格の 高騰によって，それまでの順調な経営は一転する。 経営主は種苗の購入量を減らさざるを得ず，生産 量を次第に減少させていった。それに応じて養鰻 池の数も大きく減らし，1987年に27か所存在し た加温式ハウスは, 現在では2017年には 6 か所 を残すのみとなっている（第 8 図）。跡継ぎであっ た息子も, こうした経営的な困難を受けて, 養鰻 業からの転業を決意した。さらに, 経営主自身も 高齢であるため，2005年ごろから廃業を検討す るようになったという。

こうした状況のなか, 2014年にNo.27 は, 餌 料の購入を通じて 2007 年より交流があった産地 問屋の $\mathrm{N}$ 社 ${ }^{22)}$ からの委託による生産を提案され た。すなわち, 経営体の廃業が相次ぐなか, $\mathrm{N}$ 社 でも成鰻の買い取り量を維持することが困難とな りつつあった。そこで, 種苗費, 光熱費, 餌料費 など生産に関わるすべての費用を負担する代わり に, 経営主に生産したウナギの全量を同社へ出荷 することを提案したのである。廃業を考えていた 経営主はこの提案を受け入れ，2015年より委託

22) $\mathrm{N}$ 社は, 養鰻業者への餌料販売, 養鰻業用・水産用動物の薬剂販売, 施設栽培農家向けの肥料捛よび農薬の販売 等を事業としている。2012年からは, 養鰻生産にも参入した。年間 $70 t$ の出荷を目指しているといら（N 社ホー ムページによる)。 

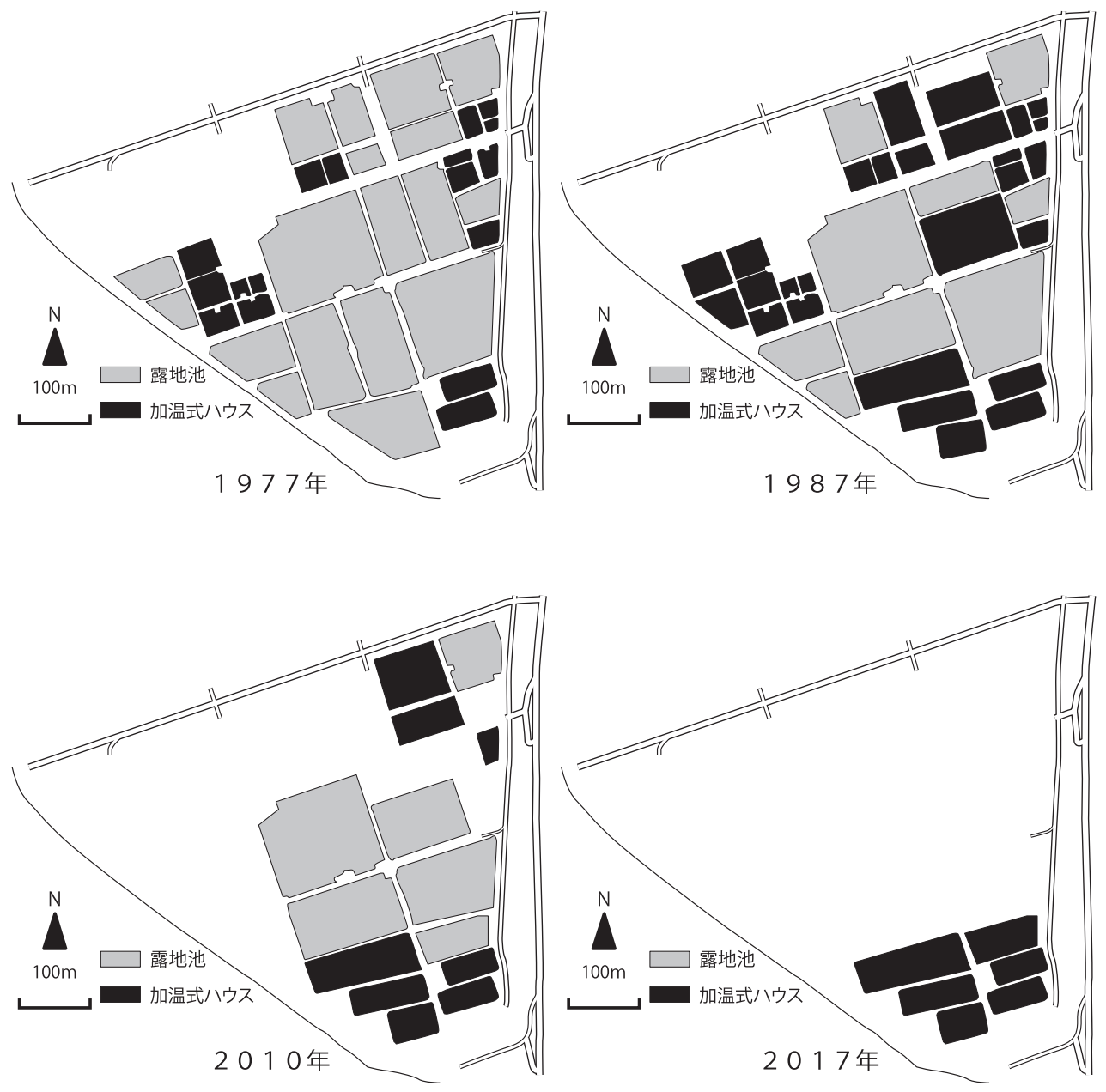

第 8 図 No.27 が所有する養鰻池の変化

Figure 8. Changes of the ponds of No.27

注 $1 ： 1977$ 年から2010年までは航空写真から作図したため，使用状況は不明である。

注 $2 ： 2017$ 年は現地調査に基づき作図したため，使用状況が反映されている。

資料 : 国土地理院航空写真, 現地調査

生産方式によって経営を維持している。また，問 屋との協力関係が構築されたことにより， $\mathrm{N}$ 社の 従業員が集出荷作業やハウスの整備を手伝うょう になった。こうして，No.27 は家族・親戚や他の 生産者の手伝いに頼らなくてもすむようになった。 以上のように, No.27 は委託生産の受け入れによ り, 経営費の軽減と労働力不足の解消を同時に達 成したのである。

\section{VI おわりに}

本稿では，西尾市一色町を事例に，養鰻産地の 経済的な変化を，産地の制度・技術的な変化と生 産者間の関係性の相互作用に焦点を当てて考察 した。

第二次世界大戦後, 一色町の養鰻業は漁協の設 立, 養鰻振興地域の指定, 養鰻業に不可欠な三要 素の確保，加温式ハウスの導入など，制度面での 整備や新規技術の導入を通じて発展してきた。特 


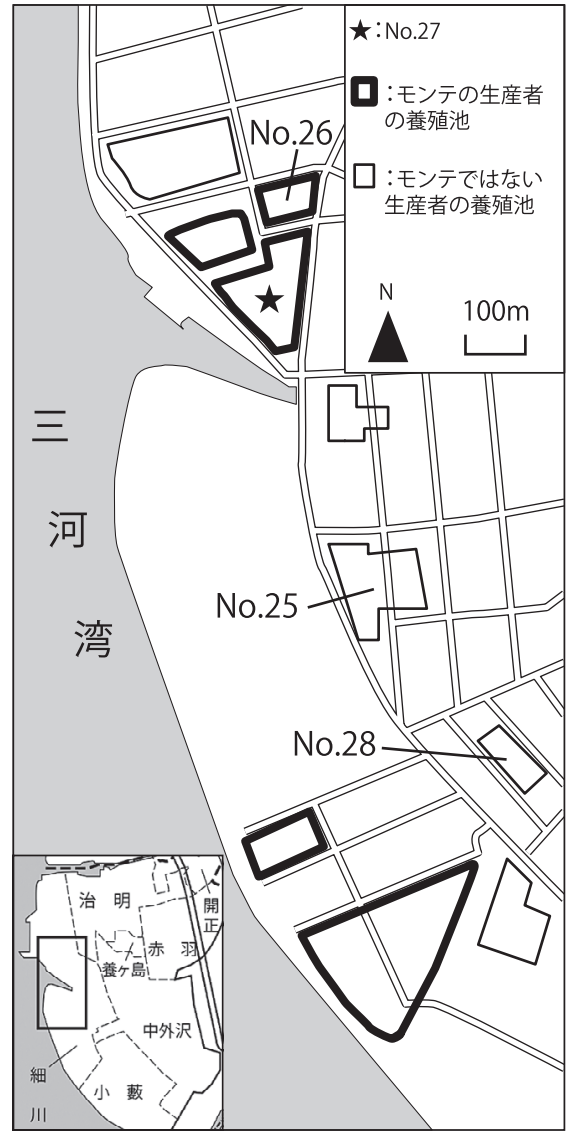

第 9 図 No.27のモンテと周辺の経営体の養鰻池（1977年）

Figure 9. Locations of the ponds of No.27's Monte, mutual assistance to work force, and around management bodies (in 1977)

注 1 : 養鰻池の範囲のため使用状況は不明。

注 2 : 図中の番号は，第 2 表の識別番号と対応する。 資料：国土地理院航空写真, 現地調査

に加温式ハウスの導入は大きな変革であり，生産 形態の変更を促し，生産量の増大に貢献した。一 方で，経営主間の関係性も，この過程において大 きく変化した。露地池を使用していた時代には， 集出荷作業をめぐる手伝い関係はほとんどの経営 体に拈いてモンテを基盤としていたが，加温式八 ウスが普及した1970年代以降では，経営体ごとに
その関係性が多様化した。本稿では，モンテを維 持している経営体, 加温式八ウスの導入による作 業の省力化に伴ってモンテを解消した経営体，ら なぎ研究会を通じてモンテよりも緩やかな関係性 を形成した経営体を見出すことができた。これら に加えて，2000年以降に種苗価格が高騰した結果， 産地問屋との関係を強め, 委託による生産を請け 負ら経営体が出現しているといら事実も明らかと なった。生産者間の関係性は一色町の養鰻業を取 り巻く社会経済的な状況や個別経営体の経営状況 と深く関連しつつ，変化してきたのである。

ただし，個別経営体への具体的な聞きとりより 得られた関係性の変化についてみると, 個人の経 験や経営体の加温式ハウスの導入，モンテに対す る考方方基づいて異なっていた。このよらな多 様性についての検討は，2015年より全国一律の 基準で実施されている養鰻業の許可制と種苗の池 入れ制限 ${ }^{23)}$, 並びに今後の制度設計を議論するら えでも重要である。

本稿では $2 つ の$ 経営体を事例として, 生産者の 具体的な関係性の変化について考察した。しかし， 生産者間での技術の交流や継承については十分に 分析されたとはいいがたい。経営形態や生産の技 術が世代間あるいは生産者間で継承されたり，生 産者の交流によって普及したりすることが，産地 の存続に与える影響は大きいと考える。特に一色 町の養鰻業は, その開始から120年余りが経過し ている。現在まで産地が維持されてきた背景を明 らかにするためにも，この点は検討しなければな らない課題である。

[付記］本稿は 2014 年 1 月に愛知教育大学に提出した卒 業論文に，その後の現地調査で得た資料を加えて執筆 したものである。内容の一部は2014年11月の人文地理 学会大会 (於広島大学) で口頭発表した。これまでご 指導を賜った伊藤貴啓先生をはじめとする愛知教育大

23) 養鰻業の許可制は，2015年 6 月 1 日から開始された。現在，許可を得た指定業者以外が養鰻業を営むことはで きない。シラスの池入れ量の制限は2015年11月より許可を得た指定業者を対象にして開始された（水産庁HP: http://www.jfa.maff.go.jp/j/saibai/unagi.html，2017年 1 月26日最終閲覧）。 
学の先生方, 並びに大学院進学後にご指導頂いている 田和正孝先生をはじめとする関西学院大学文学研究科 地理学地域学領域の諸先生方にはこの場を借りて厚く 御礼申し上げます。現地調査では，一色らなぎ漁業協 同組合の皆様, 伴健吾氏をはじめとする多数の生産者 の皆様に, ご多忙にもかかわらず多くの情報やご助言 を賜りました。ここに深く感謝申し上げます。

\section{文 献}

新井鎮久 (1976). 大井川河口養鰻地域の展開過程と河況 変動. 人文地理, 28(3), 231-256.

一色町編 (1999). ウナギ王国一色町にょろり物語. 一色 ふれあい広報, 3-9.

一色町誌編さん委員会編 (1970).『一色町誌』一色町.

井村博宣 (1987). 那賀川平野に打けるアユ養殖地域の形 成. 地理誌叢, 28(2), 85-92.

井村博宣 (1994). 那賀川平野におけるウナギ養殖地域の

形成. 地理誌叢, 35(2), 17-26.

大塚秀雄 (1996). 『鰻養殖業の経済学』農林統計協会. 海部健三 (2016).『ウナギの保全生態学』共立出版.

笠井文保 (1967). 水稲低位生産性地帯に打ける養鰻経営 の成立. 農村研究, 25, 114-132.

静岡新聞社・南日本新聞社・宮崎日日新聞社編 (2016).

『ウナギ NOW一絶滅の危機!!伝統食は守れるのか?

一』静岡新聞社.

塚本礼仁 (2000). 国内養鰻産地の維持に関する研究一熊 本県有明海沿岸玉名地区を事例として一. 文学部論 叢68 (地域科学篇), 1-22.

塚本礼仁 (2001). 養鰻産地の維持と種苗配給システムに 関する研究. 文学部論叢72 (地域科学篇), 51-65.

塚本礼仁 (2003). 鹿児島県大隅地区に打ける養殖ウナギ 産地の発展. 2003年度日本地理学会秋季学術大会発 表要旨集, 64,84 .

塚本礼仁 (2010a). 水産物フードシステムの変容と産地 の対応一ウナギを事例として一. 経済地理学年報, 56(1), 43.
塚本礼仁 (2010b). 国産ブームの到来と日本におけるウ ナギ産業の新展開. 高柳長直・川久保篤志・中川秀 一・宮地忠幸編著『グローバル化に対抗する農林水 産業』農林統計出版, 79-93.

塚本礼仁 (2014). 浜名湖ウナギ産地の変容と日本の養鰻 業. 地理, 59(10), 30-39.

白銀平・佐野雅昭 (2006). 中国に拈けるウナギ養殖産業 の展開とその条件. 地域漁業研究, 46(2), 1-21.

廣瀬慶二 (2001).『らなぎを増やす』成山堂書店. 増井好男 (1978). 養鰻産地の地域的性格一矢作川下流・ 一色町の事例一. 農村研究, 47, 73-84.

増井好男 (1979). 養鰻産地の展開過程一吉田町と大井川 町との地域的差異一. 農村研究, 48, 78-88.

増井好男 (1981). 浜名湖沿岸養鰻産地の発展過程（1） 一その形成・確立を中心に一. 農村研究, 53, 31-41.

増井好男 (1982a). 浜名湖沿岸養鰻産地の発展過程 (2) 一その成長を中心に一. 農村研究, 54, 55-66.

増井好男 (1982b). 浜名湖沿岸養鰻産地の現状と問題点. 農村研究, 55, 70-79.

増井好男 (1999).『内水面養殖業の地域分析』農林統計 協会.

増井好男 (2013).『ウナギ養殖業の歴史』筑波書房.

山内昌和 (2004). 漁業地域研究の新しいアプローチにむ けて. 人文地理, 56(4), 351-374.

山本荘毅 - 寺田 稔 - 上野泰彦 - 山内 徹 - 小島和彦 井口环也 -千沢祐之 - 田中良伸 (1980). 物部川左岸 河口地域に打ける地下水と養鰻業. 地域研究, 21(1), 36-43.

和久田清作 (1959). 愛知県における養鰻の現況. 水産増殖, 6(4), 28-32.

農林水産省 (2015). http://www.jfa.maff.go.jp/j/saibai/unagi. html「らなぎ養殖業の許可制について」（2017年 1 月26日閲覧).

農林水産省 (2017). http://www.jfa.maff.go.jp/j/saibai/unagi. html「二ホンウナギ稚魚（シラスウナギ）の池入れ 動向について」(2017年 5 月28日閲覧). 